\title{
An unusual type of Daphnia head shields from plankton and sediments of Himalayan lakes
}

\author{
Marina MANCA*, Patrizia COMOLI and Fiorenza G. MARGARITORA ${ }^{1)}$ \\ CNR Istituto Italiano di Idrobiologia, largo Tonolli, 28922 Verbania Pallanza, Italy \\ ${ }^{1)}$ Università La Sapienza, Dipartimento di Biologia Animale e dell'Uomo, V.le dell'Università, 00185, Roma, Italy \\ *e-mail corresponding author: m.manca@iii.to.cnr.it
}

\begin{abstract}
The paper reports the finding of a particular type of Daphnia (Ctenodaphnia, Dybowski \& Grochowski 1895) head shields, found in the plankton and in the sediments of two lakes in the Khumbu Region (Nepalese Himalayas). The capsules, all of the smallest size, were characterised by the presence of a hole in the medio-dorsal region, behind the posterior median groove. The location of the hole suggests a link with the nuchal organ, which we found in the neonates of the species. The finding is important for taxonomy and provides information for discussing the current hypothesis on the biogeography of the Ctenodaphnia subgenus. Being well preserved in sediment cores, the capsules are useful tools for reconstructing past phases of active reproduction which occurred also in the past.
\end{abstract}

Key words: Daphnia, head-shields, Himalayan lakes, morphology

\section{INTRODUCTORY NOTES}

We report here the finding of a particular type of Daphnia (Ctenodaphnia, Dybowski \& Grochowski 1895) head shield, found in the plankton, where individuals of Daphnia tibetana were present together with their vestigial remains, as well as in sediment cores, collected from lakes in the Himalayas (Khumbu Region, Nepal).

The lakes were sampled in the framework of the EvK2-CNR Project, an extensive pluriannual survey on the "Long Distance Transport of micro-pollutants".

\section{STUDY SITES AND SAMPLING METHODS}

Named with the cadastre numbers 29 and 40, the lakes are located, respectively, West and North of Periche (Tartari et al. 1998).

Zooplankton was collected from the two lakes (vertical hauls in the deepest point, 126 and $50 \mu \mathrm{m}$ mesh size in 1992-94, and 1997, respectively). A core from the deepest zone of L40 (core 1993/2), was collected by G.A. Tartari and M. Contesini in 1993, using a gravity corer (6 cm Plexiglass tube). The core was cut longitudinally and sliced into $1 \mathrm{~cm}$ increment in the laboratory in Italy (Guilizzoni et al. 1998). The samples were treated as in Manca \& Comoli (1995).

Both lakes have a relatively low conductivity and clear waters, with a Secchi depth down to the bottom (L40) or to $10 \mathrm{~m}$ depth (L29) (Tab. 1). Crustacean plankton is made up by four species: an endemic calanoid copepod, first described by Löffler from the same region; a Macrothrix typical of high altitude lakes, and two Daphnia species (Löffler 1968). One of these, (D. tibetana) is melanic, usually littoral; the other (D. lon- gispina) is pale and lives close to the bottom, associated with dense beds of algae and mosses (L40), or in turbid lakes (Manca et al. 1994).

\section{MORPHOLOGY OF THE CTENODAPHNIA HEAD SHIELDS AND THEIR RELATION WITH THE NUCHAL ORGAN}

We found two types of Ctenodaphnia head shields: a normal one, with the typical median groove characteristic of the subgenus (Flössner 1972; Margaritora 1983), and another, unusual, apparently not reported in the literature (Fig. 1). The main feature of the latter is a circular hole in the median region, proximal to the posterior median groove. The general shape of the two types of capsules is the same, and they belong to the same species. Indeed, they differ in size, being the "holed" capsules confined to the smallest size found in the sample ( $c$ a 280-300 $\mu \mathrm{m})$. At an intermediate size, the capsules do not retain the hole.

Given its position, in the neck region, the hole could bear some relation to the so-called "nuchal organ" ("Haft-organ"; Scourfield 1943). External cuticular structures in the neck region, termed dorsal organ, nuchal organ, neck organ or head pores, have been described for various species of the Branchiopoda and for the Crustacea in general. The dorsal organ present in Crustacea Decapoda at the naupliar stage has been regarded as homologous to the median sensory tubercle of the cephalon of some trilobites, especially Trinucleidae (Barrientos \& Laverack 1986). Recently, Olesen (1996), has established the homology between the nuchal organ of the Concostraca and the head pores of the cladoceran family Chydoridae. Dumont \& Van de Velde (1976), documented the usefulness of the structure of cladocera head pores for taxonomy. They also suggested a role in 
Tab. 1. Main features of the two lakes where the head capsules were found. The relative abundance of species composing the crustacean plankton is also reported. Note that in L40 D. tibetana was not found in the plankton.

\begin{tabular}{lcccccccc}
\hline Lakes & $\begin{array}{c}\text { Altitude } \\
(\mathrm{m} \text { a.s.1. })\end{array}$ & $\begin{array}{c}\text { Zmax } \\
(\mathrm{m})\end{array}$ & Date & $\begin{array}{c}\text { Cond.20 } \\
(\mu \mathrm{C} \mathrm{cm})^{-1}\end{array}$ & $\begin{array}{c}\text { Arctodiaptomus } \\
\text { jurisovitchi }\end{array}$ & $\begin{array}{c}\text { Daphnia } \\
\text { longispina }\end{array}$ & $\begin{array}{c}\text { Daphnia } \\
\text { tibetana }\end{array}$ & $\begin{array}{c}\text { Macrothrix } \\
\text { hirsuticornis }\end{array}$ \\
\hline L29 & 5172 & 20 & Sep 97 & 12 & +++ & + & + \\
L40 & 5220 & $5-8$ & Oct 93 & 8 & + & +++ & + \\
\hline
\end{tabular}
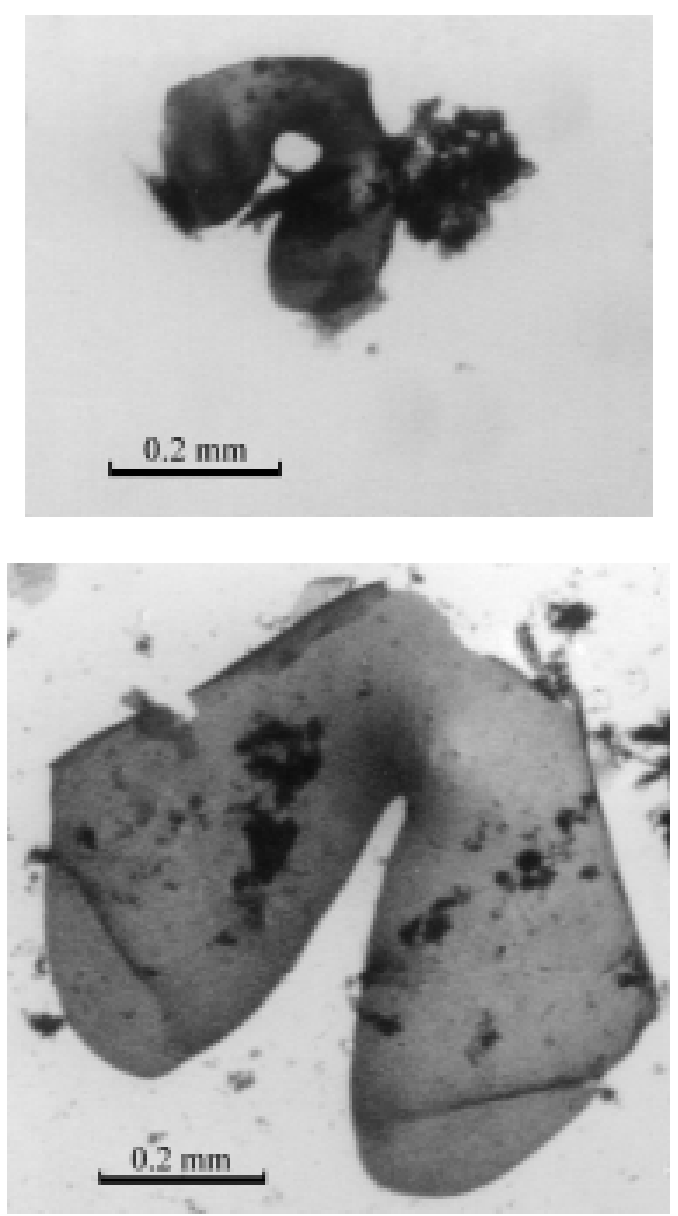
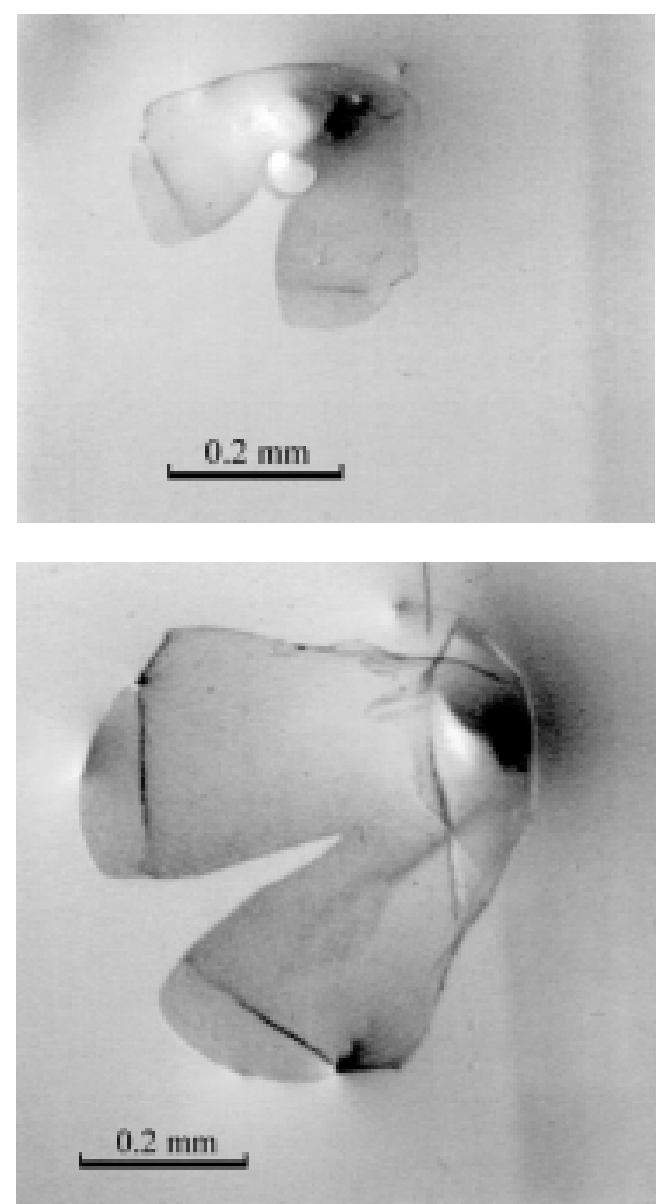

Fig. 1. Head capsules of Daphnia (Ctenodaphnia) tibetana from L40 core sediments (left side) and from living organism of L29.

mechanoreception of the external cuticular structures, and of the underlying tissues in the region of the nuchal organ.

Most cladocerans show the typical arrangement of a more or less circular cuticular area surrounded by an elevated rim which is also seen in some species of the Conchostraca and Anostraca. This neck organ morphology exists in the cladoceran order Onychopoda, and in anomopoda (Macrothricidae; Daphniidae). In one species of the genus Simocephalus, it is modified into an attachment organ, acting as a supplement to the normal antennal way of attachment (Meyer-Rochow 1979). Sida crystallina is the only species of Ctenopoda known to have a neck organ, and it is the most well documented example of a neck organ modified into an attaching device (Günzl 1978, 1980). The homology with the nuchal organ is not obvious from adult specimens but is apparent when juveniles are examined.

The organ is committed to osmoregulation (Halcrow 1982; Aladin 1991), also in predatory species (Halcrow 1985). Cladocera are able to osmoregulate (both hyperosmotic and hypoosmotic regulation of hemolymph, in fresh to slightly brackish and in marine waters, respectively). While in marine organisms the nuchal organ can be active also at the adult stage, there is no trace of it in Daphnia adults: in the latter, the hyperosmotic regulation is mainly determined by the amount of salts consumed with the food (Aladin 1991; Halcrow 1982, 1985; Aladin \& Valdivia Villar 1987). The organ is essential for the survivorship of embryos in the last two stages within the brood pouch, because they are not able to feed. After leaving the brood pouch, the young 

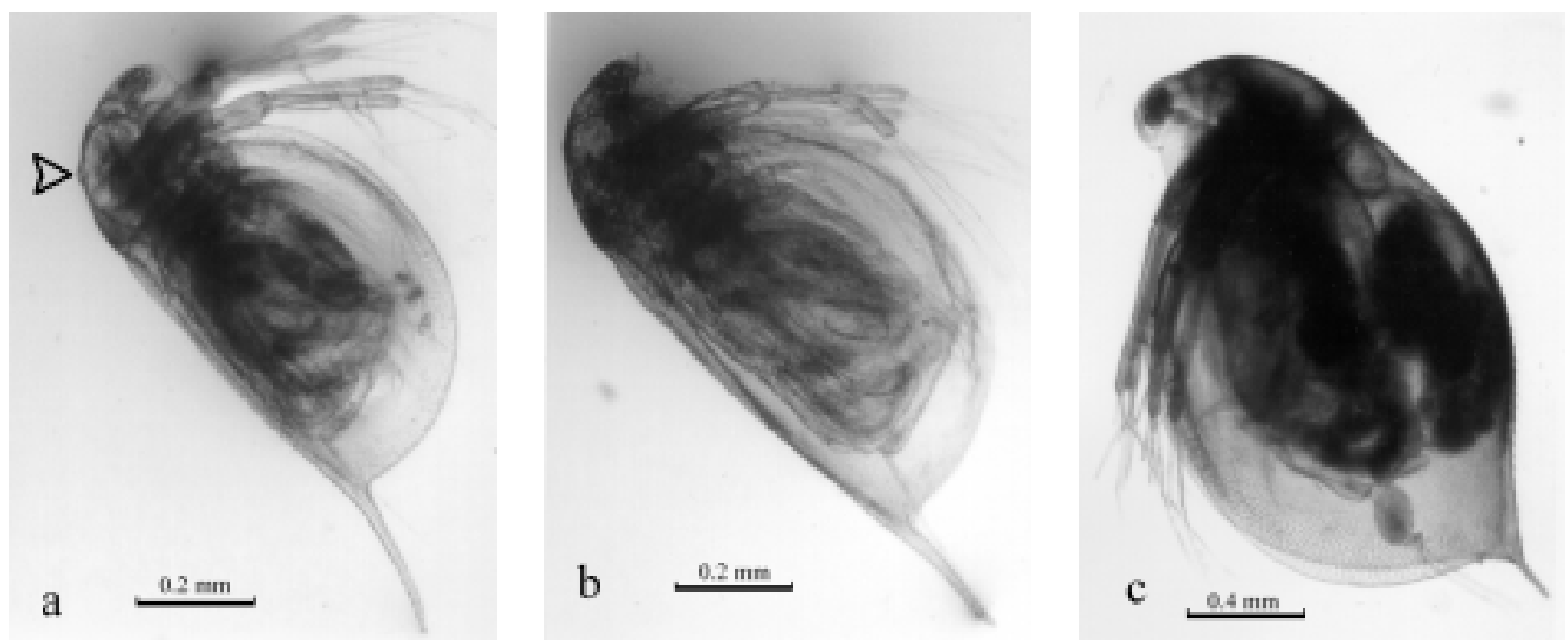

Fig. 2. Daphnia tibetana from the plankton sample of L29. a: neonate with the neck organ well visible on the dorsal margin of the head shield; b: intermediate size; c: adult parthenogenetic female with embryos.

cladocera can feed, and with the first post-embryonal moulting, the organ disappears. In species with closed brood pouch, hypo-osmoregulation is maintained by the pouch itself, until the final stages of development of embryos, when the nuchal organ or the epipodites develop. At that moment, the marsupial fluid rises in concentration to that of the surrounding sea or brackish water (Aladin 1991).

The smallest individuals of $D$. tibetana from the plankton of L29, probably neonates just released from the mother's brood pouch, retain the nuchal organ in the same zone where the hole of the smallest capsules is found (Fig. 2a). It is located anterior to the insertion of the second muscle of antennae, a location which is considered as a diagnostic trait for the subgenus Ctenodaphnia (Schwartz \& Hebert 1984). There is no trace of the nuchal organ in the other two pre-adult and adult stages (Figs 2b, 2c).

The presence of the nuchal organ at the first instar, as well as its early disappearance with the first moult has been reported for Daphnia (Ctenodaphnia) magna (Halcrow 1982; Aladin 1991). Therefore, the presence and location of this structure in neonates of D. tibetana, never reported so far, is a trait which confirms the diagnosis of Daphnia tibetana as a Ctenodaphnia (Manca \& Hann 1999). Also new is the report of the "holed" capsules typical of neonates, as well as their finding in a sediment core. Even from the two SEM pictures of the dorsal part of the head of a D. magna newborn reported in Aladin (1991), it is difficult to argue the presence of a large hole. We did not find it in the few available pictures of head capsules of newborn Cladocera. Adults, even of those species which retain the nuchal organ, have pores instead of a single, large hole (Dumont \& Van de Velde 1976).

The two types of head capsules were found in the plankton of L29 and in the sediment core of L40. (core
1993/2; Figs 2 and 4). D. longispina is the only Daphnia species of the recent plankton of L40 (Tab. 1 and Manca et al. 1998). This is also confirmed by the finding of head capsules of $D$. longispina-type only in the upper 3 $\mathrm{cm}$ of the upper sediment sequence. Below $8 \mathrm{~cm}$, only Daphnia (Ctenodaphnia) tibetana capsules are present, with the exception of a level where capsules of the two Daphnia species co-occur. Along the core, small, "holed" capsules are usually found in higher percentages than the "normal" ones. Samples analysed so far are incomplete, and we definitely need more data, to discuss the entire sediment sequence. However, the finding of the two types of Ctenodaphnia head capsules in the core is interesting per se, being never reported before.

\section{CONCLUDING REMARKS}

The presence of an unique central and large hole in head capsules of young Daphnia tibetana may be regarded as a retention of an ancestral character. Its location, as well as that of the nuchal organ related to it, is an important trait for the attribution of the species to the subgenus Ctenodaphnia, as already suggested by Manca et al. (1994). The finding is not irrelevant, especially for the biogeography of the two subgenera. Species in Ctenodaphnia predominate in India, Australia, Africa and South America, whereas species in the nominate subgenus are dominant in North America and Eurasia (Schwartz \& Hebert 1984). This distribution pattern led to the suggestion that the genus Daphnia evolved before the division of the Laurasian and Gondwanalandian land masses. Himalayas are extremely interesting in this respect, as they were formed after the separation of the two continental masses. The attribution to Ctenodaphnia of the Daphnia species endemic of a region in the Himalayas is very important, and we need further information to find whether holed capsules are restricted to young tibetana. 


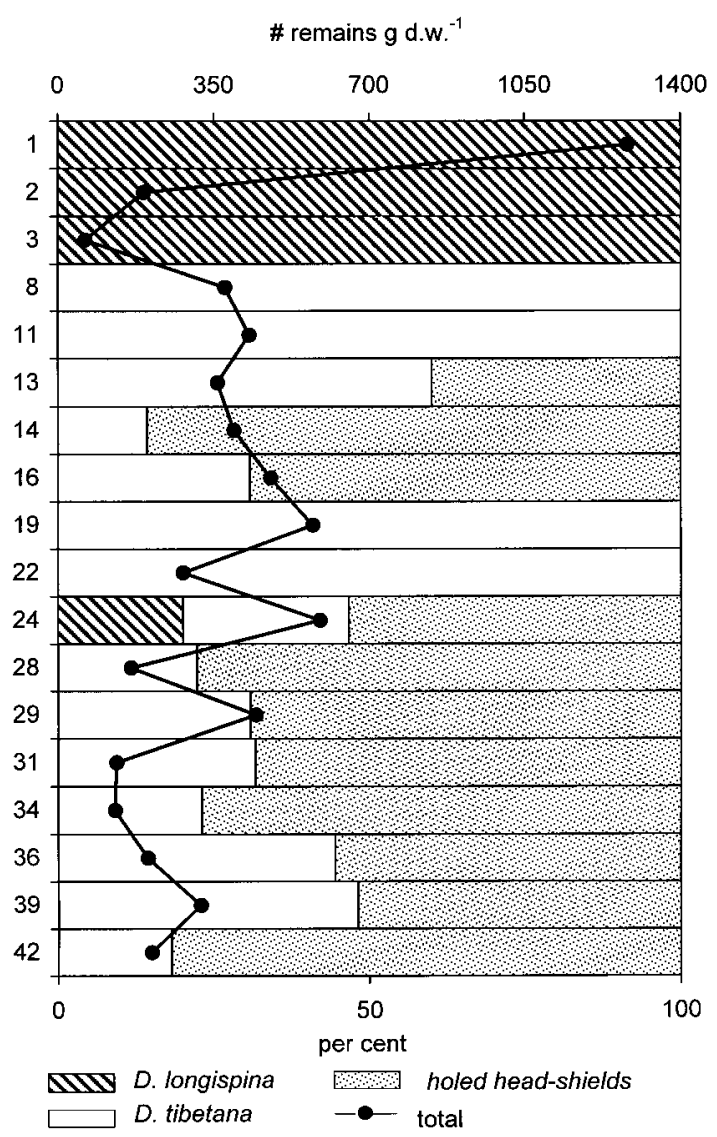

Fig. 3. Sediment sequence of cladocera remains from L40 (core 1993/2): the line indicates total concentration and the bars the relative abundance of the different types of Daphnia and Ctenodaphnia head capsules.

Maybe the absence of predators or the low developmental times enables the finding of this morphological feature which in other environments cannot simply be seen. Certainly the possibility to recognise this type of capsules, typical of the new-born in a core sequence allows the reconstruction of periods of different reproductive activity. Last but not least, the disappearance of D. tibetana from the recent sediments of L40, and its absence from the plankton of this lake is rewarding: are we losing biodiversity in an environment, which belong to those defined as "treasures" of biological diversity? Maybe it is not just by chance that no holed capsules were found in the sediment sections deposited immediately before the disappearance of the Ctenodaphnia-type Daphnia.

\section{REFERENCES}

Aladin, N.V. \& R.S. Villar Valdivia. 1987. Microcryoscopical investigation of the liquid from maxillary grand of Daphnia magna Straus durign acclimation to different salinities. Hydrobiol. J., 23: 93-97.

Aladin, N.V. 1991. Salinity tolerance and morphology of the osmoregulation organs in Cladocera with special reference to Cladocera from the Aral Sea. Hydrobiologia, 225: 291299.

Barrientos, Y. \& M.S. Laverack. 1986. The larval crustacean dorsal organ and its relationship to the trilobite median tubercle. Lethaia, 19(4): 309-313.

Guilizzoni, P., A. Lami, J.D. Smith, C. Belis, M. Bianchi, R. Bettinetti, A. Marchetto \& H. Muntau. 1998. Palaeolimnological analysis of some Himalayan lakes (Khumbu Valley, Nepal). Ecovision World Monograph series: 189217.

Dumont, H.J. \& I. Van de Velde. 1976. Some types of headpores in the Cladocera as seen by the scanning elektron microscopy and thier possible functions. Bio. $\mathrm{Jb}$. Dodonaea, 44: 135-142.

Flössner, D. 1972. Krebstiere, Crustacea. Kiemen -und Blatfüsser, Branchiopoda Fischlauser, Branchiura. Tierw. Deutsch., 60: 500 pp.

Günzl, H. 1978. Der Ankerapparat von Sida crystallina (Crustacea, Cladocera). I Bau un Funktion. Zoomorphology, 90: 197-204.

Günzl, H. 1980. Der Ankerapparat von Sida crystallina (Crustacea, Cladocera). II Feinbau und neubildung. Zoomorphology, 95: 149-157.

Halcrow, W. 1982. Some ultrastructutral features of the nuchal organ of Daphnia magna Straus (Crustacea: Branchiopoda). Can. J. Zool., 60: 1257-1264.

Halcrow, W. 1985. A note on the significance of the neck organ of Leptodora kindtii (Focke) (Crustacea: Cladocera). Can. J. Zool., 63: 738-740.

Löffler, H. 1968. Diaptomus (Arctodiaptomus jurisovitchi nov. Spec.) aus dem Khumbu-Gebiet (Nepal). Khumbu Himal., 3: 9-16.

Manca, M., P. Cammarano \& T. Spagnuolo. 1994. Notes on Cladocera an Copepoda from high altitute lakes in the Mount Everest Region (Nepal). Hydrobiologia, 287: 225231.

Manca, M. \& P. Comoli. 1995. Temporal variations of fossil Cladocera in the sediments of Lake Orta (N. Italy) over the last 400 years. J. Paleolimnol., 14: 113-122.

Manca, M., D. Ruggiu, P. Panzani, A. Asioli, G. Mura \& A.M. Nocentini. (1998). Report on a collection of aquatic organisms from high mountain lakes in the Khumbu Valley (Nepalese Himalayas). Mem. Ist. ital. Idrobiol., 57: in press.

Manca, M. \& B.J. Hann. 1999. Redescription of Daphnia tibetana (Daphniopsis tibetana Sars, 1903). Journal of crustacean Biology: in press.

Margaritora, F.G. 1983. Cladoceri (Crustacea: Cladocera). Consiglio Nazionale delle Ricerche AQ/I/197, Guide per il riconoscimento delle specie animali delle acque interne italiane, 22: $169 \mathrm{pp}$.

Tartari, G.A., G. Tartari \& R. Mosello. (1998). Chemistry of high altitude lakes in the Khumbu Valley (Nepalese Himalayas). Mem. Ist. ital. Idrobiol., 57: in press.

Meyer-Rocow, V.B. 1979. The attachment mechanism of the waterflea Simocephalus. Microscopy, 33: 551-553.

Olesen, J. 1996. External morphology and phylogenetic significance of the dorsal/neck organ in the Conchostraca and the head pores of the cladoceran family Chydoridae (Crustacea, Branchiopoda). Hydrobiologia, 330: 213-226.

Schwartz, S.S. \& P.D.N. Hebert. 1984. Subgeneric distinction in the genus Daphnia: a new diagnostic trait. Trans. Am. Microsc. Soc., 103(4): 341-346.

Scourfield, D.J. 1943. The post-emberyonal development of the male of Daphnia magna. J. Queckett Microsc. Club Sec., 4(1): 276-283. 